\title{
Evaluation of mortality predictors in hospitalized COVID-19 patients: Retrospective cohort study
}

\author{
Melahat UZEL ŞENER ${ }^{1}$ (ID \\ Murat YILDIZ $^{1}$ (ID) \\ Suna KAVURGACI ${ }^{1}$ (ID) \\ Figen ÖZTÜRK \\ ERGÜR $^{\mathbf{1}}(\| \mathrm{D})$ \\ Alp ŞENER ${ }^{2}(\mathrm{ID})$ \\ Ayperi ÖZTÜRK ${ }^{1}(I D)$
}

${ }^{1}$ Clinic of Chest Diseases, University of Health Sciences, Atatürk Chest Diseases and Chest Surgery Training and Research Hospital, Ankara, Turkey

1 Sağlık Bilimleri Üniversitesi, Atatürk Göğüs Hastalıkları ve Göğüs Cerrahisi Ĕgitim ve Araştırma Hastanesi, Göğüs Cerrahisi Kliniği, Ankara, Türkiye

2 Department of Emergency Medicine, Yıldırım Beyazıt University Facultyof Medicine, Ankara, Turkey

2 Yıldırım Beyazıt Üniversitesi Tıp Fakültesi, Acil Tıp Anabilim Dalı, Ankara, Türkiye
Cite this article as: Uzel şener $M$, Yıldız M, Kavurgacı $S$, Öztürk Ergür $F$, Sener A, Öztürk A. Evaluation of mortality predictors in hospitalized COVID-19 patients: Retrospective cohort study. Tuberk Toraks 2021;69(2):196-206.

\section{Yazışma Adresi (Address for Correspondence)}

\section{Dr. Melahat UZEL SSENER}

Sağlık Bilimleri Üniversitesi, Atatürk Göğüs Hastalıkları ve

Göğüs Cerrahisi Eğitim ve Araş̧ırma Hastanesi, Göğüs Hastalıkları Kliniği,

ANKARA - TÜRKIYE

e-mail: melahatuzeldr@yahoo.com.tr

CCopyright 2021 by Tuberculosis and Thorax.

Available on-line at www.tuberktoraks.org.com

\begin{abstract}
Evaluation of mortality predictors in hospitalized COVID-19 patients: Retrospective cohort study

Introduction: Evaluation of parameters that will predict prognosis in COVID19 disease ensures correct determination of treatment strategy. In this study, it was aimed to determine the clinical, radiological and laboratory parameters affecting mortality and to evaluate the risk factors.
\end{abstract}

Materials and Methods: Patients hospitalized with the diagnosis of COVID-19 in September 2020 were included in the study. Clinical features, laboratory parameters, and radiological findings at admission were recorded. The relationship of these parameters with 30-day mortality was evaluated. Statistical analysis was performed with SPSS for Windows 16.0 Package Program.

Results: Three hundred and sixty patients (female/male, $n=228 / 132$ ) hospitalized in the specified period were included in the study. 30-day mortality rate was $14.4 \%$ in all patients. In multiple logistic regression analysis, age, presence of heart failure, admission oxygen saturation, body temperature higher than 38.2 and high ferritin levels were evaluated as independent risk factors for 30-day mortality.

Conclusion: The relationship between clinical and laboratory markers and mortality is very important for the correct orientation of healthcare services and the correct determination of treatment strategy during the COVID-19 pandemic.

Key words: COVID-19; pandemic; prognosis; mortality; ferritin 


\section{ÖZ}

\section{Hastaneye yatan COVID-19 hastalarında mortalite belirteçlerinin değerlendirilmesi: Retrospektif kohort çalışması}

Giriş: COVID-19 hastalığında prognoz tahmin ettirecek parametrelerin saptanması tedavi stratejisinin doğru belirlenmesini sağlamaktadır. Bu çalışmada mortaliteye etki eden klinik, radyolojik ve laboratuvar parametrelerinin belirlenmesi, risk faktörlerinin değerlendirilmesini amaçlanmıştır.

Materyal ve Metod: Eylül 2020'de COVID-19 tanısı ile hastaneye yatırılan hastalar çalışmaya dahil edildi. Başvuru sırasındaki klinik özellikleri, laboratuvar parametreleri, radyolojik bulguları kaydedildi. Bu parametrelerin 30 günlük mortalite ile ilişkisi değerlendirildi. Istatistiksel analizler SPSS-for-Windows 16.0 Paket Programı ile yapıldı.

Bulgular: Belirtilen sürede hastaneye yatan 360 hasta $(228 / 132, K / E)$ çalışmaya alındı. Tüm hastalarda 30 günlük mortalite oranı $14,4 \%$ saptandı. Çoklu Lojistik regresyon analizinde yaş, kalp yetmezliği varlığı, başvuru oksijen satürasyonu, vücut sıcaklı̆̆ının 38,2'den yüksek olması ve yüksek ferritin düzeyleri 30 günlük mortalite için bağımsız risk faktörleri olarak değerlendirildi.

Sonuç: Klinik ve laboratuvar belirteçler ile mortalite arasındaki ilişki, COVID-19 salgını sırasında sağlık hizmetlerinin doğru yönlendirilmesi ve tedavi stratejisinin doğru belirlenmesi açısından çok önemlidir.

Anahtar kelimeler: COVID-19; pandemi; prognoz; mortalite; ferritin

\section{INTRODUCTION}

Coronavirus disease-19 (COVID-19) outbreak that emerged in December 2019 in Wuhan still goes on unabated worldwide. Since the clinical course varies from mild disease to death $(1,2)$, there is a need for certain parameters that can predict the prognosis at the time of patient's admission to the hospital and enable the relevant healthcare professionals to make the appropriate treatment decisions (3).

The rate of the patients, who were provided intensive care support among the patients admitted to the hospitals, had reached $6 \%$ in China and that the respective rates in U.K. and in Europe in general were even higher. Therefore, availability of such data that can be used to predict mortality or severe course of the disease would enable the healthcare professionals to properly distribute and use their energy and the available medical support $(2,4)$.

During the pandemic period, clinics started to rapidly share their data in order to be able to create a common treatment modality and a follow-up approach. A review of the published studies reveals the differences between these laboratory data, which might be helpful in predicting the prognosis $(2,3)$.

Hence, it was aimed with this study to investigate the relationship between clinical, laboratory and radiological findings and mortality in hospitalized patients and to determine the risk factors related to the prognosis.

\section{MATERIALS and METHODS}

The ethics committee approval was obtained from the local ethics committee in which the study was conducted.

\section{Patients}

The patients aged 18 years and above, who presented to the hospital between September $1^{\text {st }}$ and September $30^{\text {th }}, 2020$ and who were hospitalized with a diagnosis of COVID-19 via reverse transcriptase polymerase chain reaction (RT-PCR) positivity were included in the study. The data was retrospectively scanned from the database. The patients, who were hospitalized with suspected COVID-19 but tested negative for COVID-19 on RT-PCR test, who were younger than 18 years of age, who were provided outpatient treatment only, were excluded. Patients' age, sex, body-mass index, symptoms at admission time from onset of symptoms to admission to the hospital, comorbidities, and the medications used were recorded. Fever and oxygen saturation $\left(\mathrm{SO}_{2}\right)$ levels detected at admission were recorded. Duration of hospital stay, need for intensive care, mortality and survival were evaluated. Thirty-day medical surveillance has begun with the admission to the hospital, and the mortalities in this period were recorded.

The patients' data of treatments were also recorded. In this context, whether the need has arisen to administer broad spectrum antibiotics, nasal oxygen or high flow oxygen were noted.

\section{Laboratory}

Laboratory parameters of the patients both on the first day and discharge were recorded. These parameters primarily included white blood cell (WBC), hemoglobin (HB), platelet (PLT), lymphocyte (LYM), neutrophil $(\mathrm{NE})$, creatinine, C-reactive protein (CRP), aspartate aminotransferase (AST), alanine aminotransferase $(\mathrm{ALT})$, sodium $(\mathrm{Na})$, calcium $(\mathrm{Ca})$, troponin, ferritin, and D-dimer levels. 


\section{Radiology}

Radiological findings (chest X-ray and computed tomography $(\mathrm{CT})$ ) on first day visit were noted. Chest $\mathrm{X}$-ray findings were categorized into three groups: normal, unilateral, and bilateral infiltrates. Additionally, CT findings were re-evaluated by two experienced clinicians. CT findings were categorized both based on the number of lobes involved (unilateral or bilateral), and the location of the involvement (central and/or peripheral). While on CT, findings with ground glass and/or consolidation detected in more than $50 \%$ of the total area were defined as "diffuse involvement", those with less than $50 \%$ were defined as "limited involvement". CT scans performed during the hospital stay were not taken into consideration.

These clinical, laboratory and radiological findings were reviewed within the scope of the 30-day medical surveillance period to determine the factors affecting mortality.

\section{Statistical Analysis}

Statistical analysis of the study was performed with SPSS for Windows 16.0 Package Program. Normality analysis of continuous data was performed with Shapiro-Wilk test, QQ-plot and histogram graphics. It was accepted that a $p<0.05$ level in the ShapiroWilk test did not provide the assumption of normality. For normally distributed variables, Independent Samples-t test was used for mean comparisons between two independent groups, and variables were expressed as mean, standard deviation and 95\% confidence interval. For the variables assumed to be not normally distributed, Mann-Whitney $U$ test was used for comparisons between two independent groups, and variables were expressed as median and interquartile range. Chi-square tests were used to compare the frequency distributions of categorical variables, and these variables were expressed with sample count and percentage. Multiple logistic regression analysis was performed for parameters evaluated to be significantly in terms of survival in univariate analyzes. In this analysis, Odds ratios are presented with $95 \%$ confidence intervals for the potential predictors of mortality. $\mathrm{p}<0.05$ level was used for statistical significance.

\section{RESULTS}

Three hundred and sixty patients (228/132, M/F) admitted to the hospital and received inpatient between September $1^{\text {st }}$ and September $30^{\text {th }}, 2020$ were included into the study. Mean age of patients was $62.3 \pm 14.1 .88 .3 \%$ of the patients who received inpatient were discharged, whereas $11.7 \%$ of them had died. The patients' 30-day mortality rate after being diagnosed with COVID-19 was $14.4 \%$ (Table 1).

According to the univariate analysis of the factors affecting 30 day mortality, $76.9 \% \quad(n=40)$ of the patients were male in the mortality group, which indicated that mortality rate was significantly higher in male patients $(p<0.05)$ (Table 1).

While mean age was as $60.8 \pm 13.7$ years in the survival group, it was $71.2 \pm 13.0$ years in the mortality group ( $\mathrm{p}<0.05)$. Mean BMI was 28.6 (26.3-31.7) and 27.9 (24.1-30.2) in the survival and mortality group, respectively. No significant relationship was found between $\mathrm{BMI}$ and mortality $(\mathrm{p}=0.066)$. Although the patients' complaints at admission included cough, shortness of breath (dyspnea), sore throat, fever $\left(>38.2^{\circ} \mathrm{C}\right)$, diarrhea, taste and smell loss, and myalgia, mortality was found to be statistically higher in patients presented with dyspnea $(p<0.05)$. Median time elapsed from the onset of symptoms till the admission to the hospital was determined in the surviving group as seven days (min: 4, max: 8 day), and it was detected significantly longer than according to the mortality group $[4$ days $(\min : 3, \max : 7),(p<$ 0.05)] (Table 1).

In patients with at least one comorbidity, survival and mortality rates were determined as $69.2 \%$ and $88.5 \%$, respectively $(p<0.05)$. When mortality rate was reviewed by comorbidities, it was significantly higher in patients with congestive heart failure (CHF) and chronic obstructive pulmonary disease (COPD) $(p<0.05$ and $p<0.01$, respectively). No statistically significant relationship was found between mortality and comorbidities such as hypertension (HT), diabetes mellitus (DM), coronary artery disease (CAD), asthma, malignancy, chronic kidney disease (CKD), interstitial lung disease (ILD) and rheumatologic diseases. Median value of oxygen saturation recorded at admission was found to be significantly higher in the survival group than in the mortality group [90 (8594), 80 (75-88), respectively, $p<0.001]$ (Table 1).

The analysis of the relationship between laboratory parameters and mortality revealed that lymphocyte count was statistically significantly higher in the survival group than in the mortality group, whereas 
Table 1. Univariate analysis in groups according to 30-day survival- demographics

\begin{tabular}{|c|c|c|c|c|c|}
\hline \multirow{3}{*}{ Variables } & \multicolumn{5}{|c|}{ 30-day survival } \\
\hline & \multicolumn{2}{|c|}{$\begin{array}{c}\text { Survival } \\
\mathrm{n}=308(85.6 \%)\end{array}$} & \multicolumn{2}{|c|}{$\begin{array}{c}\text { Mortal } \\
\mathrm{n}=52(14.4 \%)\end{array}$} & \multirow[b]{2}{*}{$\mathbf{p}$} \\
\hline & Row, n (\%) & Median (IQR) & Row, n (\%) & Median (IQR) & \\
\hline Age, mean $\pm \mathrm{SD}(\% 95 \mathrm{Cl})^{\dagger}$ & & $60.8 \pm 13.7(59.2-62.3)$ & & $71.2 \pm 13.0(67.6-74.8)$ & $<0.001$ \\
\hline $\mathrm{BMI}^{\ddagger}$ & & $28.6(26.3-31.7)$ & & $27.9(24.1-30.2)$ & 0.066 \\
\hline Hospitalization (day) $)^{\ddagger}$ & & $7(4-9)$ & & $7(3-10)$ & 0.468 \\
\hline Time to admission ${ }^{\ddagger}$ & & $7(4-8)$ & & $4(3-7)$ & 0.006 \\
\hline \multicolumn{6}{|l|}{ Sex* } \\
\hline Male & $188(82.5)$ & & $40(17.5)$ & & \multirow[b]{2}{*}{0.028} \\
\hline Female & $120(90.9)$ & & $12(9.1)$ & & \\
\hline Repeated hospitalization ${ }^{\S}$ & $15(88.2)$ & & $2(11.8)$ & & 1.000 \\
\hline Cough* & $166(86.0)$ & & $27(14.0)$ & & 0.792 \\
\hline Shortness of breath* & $193(81.8)$ & & $43(18.2)$ & & 0.005 \\
\hline Sore throat* & $46(83.6)$ & & $9(16.4)$ & & 0.660 \\
\hline Fever* & $139(83.2)$ & & $28(16.8)$ & & 0.244 \\
\hline Diarrhea* & $31(86.1)$ & & $5(13.9)$ & & 0.909 \\
\hline Taste/smell loss $\$$ & $16(94.1)$ & & $1(5.9)$ & & 0.485 \\
\hline Myalgia* & $200(87.7)$ & & $28(12.3)$ & & 0.125 \\
\hline Contact history* & $105(84.7)$ & & $19(15.3)$ & & 0.731 \\
\hline Comorbid disease* & $213(82.2)$ & & $46(17.8)$ & & 0.004 \\
\hline $\mathrm{HT}^{*}$ & $125(83.3)$ & & $25(16.7)$ & & 0.311 \\
\hline $\mathrm{DM}^{*}$ & $87(83.7)$ & & $17(16.3)$ & & 0.513 \\
\hline CAD* & $50(82.0)$ & & $11(18.0)$ & & 0.382 \\
\hline $\mathrm{CHF}^{\S}$ & $12(60.0)$ & & $8(40.0)$ & & 0.004 \\
\hline COPD* & $35(68.6)$ & & $16(31.4)$ & & $<0.001$ \\
\hline Asthma ${ }^{\S}$ & $20(80.0)$ & & $5(20.0)$ & & 0.383 \\
\hline Malignancy* & $29(78.4)$ & & $8(21.6)$ & & 0.193 \\
\hline $\mathrm{CKD}^{\S}$ & $10(71.4)$ & & $4(28.6)$ & & 0.128 \\
\hline $\operatorname{ILD}^{\S}$ & $1(50.0)$ & & $1(50.0)$ & & 0.270 \\
\hline Rheumatological ${ }^{\S}$ & $8(80.0)$ & & $2(20.0)$ & & 0.643 \\
\hline \multicolumn{6}{|c|}{$\begin{array}{l}\text { IQR: Interquartile range, SD: Standard deviation, Cl: Confidence interval, BMI: Body mass index, HT: Hypertension, CAD: Coronary artery disease, } \\
\text { CHF: Congestive heart failure, COPD: Chronic obstructive pulmonary disease, CKD: Chronic kidney disease, ILD: Interstitial lung disease. } \\
\left.{ }^{+} \text {Independent Samples-t test [mean } \pm \mathrm{SD}(\% 95 \mathrm{Cl})\right] \text {. } \\
{ }^{\ddagger} \text { Mann-Whitney U test [median (IQR)]. } \\
\text { * Pearson Chi-square test [n }(\%)] . \\
\S \text { Fisher's exact test }[\mathrm{n}(\%)] .\end{array}$} \\
\hline
\end{tabular}

neutrophil count, creatinine, CRP, D-dimer, ferritin, and troponin levels were statistically significantly higher in the mortality group than in the survival group $(\mathrm{p}<0.001)$ (Table 2) (Figure 1).

Although hemoglobin, AST and calcium levels in the mortality group were also found statistically significantly higher, these results were not considerable clinically. The relationship between radiological findings and mortality was not statistically prominent. However, a statistically expressive was determined in terms of mortality rates between the patients with limited and diffuse involvement on CT. The ratio of patients with diffuse involvement was $59 \%$ in the mortality group $(p<0.05)$ (Table 3$)$. There was no mortality in the patient group who needed no oxygen 
Table 2. Univariate analysis in groups according to 30-day survival vital signs and laboratory

\begin{tabular}{|c|c|c|c|c|c|}
\hline \multirow{3}{*}{ Variables } & \multicolumn{5}{|c|}{ 30-day survival } \\
\hline & \multicolumn{2}{|r|}{ Survival } & \multicolumn{2}{|r|}{ Mortal } & \multirow[b]{2}{*}{$\mathbf{p}$} \\
\hline & Row, n (\%) & Median (IQR) & Row, n (\%) & Median (IQR) & \\
\hline \multicolumn{6}{|l|}{ BT (degrees C)* } \\
\hline$\leq 38.2$ & $270(87.7)$ & & $38(12.3)$ & & \multirow{2}{*}{0.013} \\
\hline$>38.2$ & $38(74.5)$ & & $13(25.5)$ & & \\
\hline $\mathrm{SO}_{2}$ (pulse oximeter) & & $90(85-94)$ & & $80(75-88)$ & $<0.001$ \\
\hline WBC & & $6740(4960-8800)$ & & $7465(5365-11375)$ & 0.055 \\
\hline Lymphocyte & & $1100(820-1610)$ & & 745 (540-1090) & $<0.001$ \\
\hline Neutrophil & & $4805(3350-6745)$ & & $5725(3830-8810)$ & 0.011 \\
\hline Monocyte & & $400(290-580)$ & & $390(265-590)$ & 0.927 \\
\hline Eosinophil & & $2(0-20)$ & & $0(0-10)$ & 0.051 \\
\hline Hemoglobin & & $13.8(12.5-14.95)$ & & $12.8(11-14.35)$ & 0.002 \\
\hline Platelet & & $211500(166500-288000)$ & & $194000(140500-251000)$ & 0.066 \\
\hline Creatinine & & $0.97(0.82-1.15)$ & & $1.25(0.9-1.61)$ & $<0.001$ \\
\hline ALT & & $26(17-40)$ & & $28(19-41.5)$ & 0.653 \\
\hline AST & & $32(23-49)$ & & $44(30-54)$ & 0.009 \\
\hline $\mathrm{Na}$ & & $136(134-139)$ & & $136(133-139)$ & 0.572 \\
\hline $\mathrm{Ca}$ & & $8.8(8.3-9.2)$ & & $8.4(8.1-8.7)$ & $<0.001$ \\
\hline CRP & & $79.5(28-132)$ & & $129(54.92-177)$ & 0.001 \\
\hline INR & & $0.99(0.92-1.09)$ & & $1.11(0.98-1.36)$ & 0.024 \\
\hline D-dimer & & 755 (460-1560) & & $1440(510-2130)$ & 0.022 \\
\hline Ferritin & & 309.5 (141.9-601.15) & & $480.5(301-792)$ & 0.011 \\
\hline Troponin & & $6.71(3.47-13.87)$ & & $18.27(10.28-44.49)$ & $<0.001$ \\
\hline Creatinine ( $3^{\text {rd }}$ day) & & $0.87(0.75-1.05)$ & & $1.23(0.96-1.61)$ & $<0.001$ \\
\hline $\operatorname{ALT}\left(3^{\text {rd }}\right.$ day $)$ & & $34(21-52)$ & & $25(17-45)$ & 0.145 \\
\hline AST ( $3^{\text {rd }}$ day) & & $31(22-46)$ & & $32(24-51)$ & 0.235 \\
\hline CRP ( $3^{\text {rd }}$ day) & & 36.55 (13.9-89) & & $77.14(44.11-126.73)$ & $<0.001$ \\
\hline Ferritin ( $3^{\text {rd }}$ day) & & $377(185.7-723.3)$ & & $600.65(316.5-936.85)$ & 0.018 \\
\hline WBC ( $5^{\text {th }}$ day $)$ & & 8690 (5950-11250) & & $10360(7950-14280)$ & 0.012 \\
\hline Platelet ( $5^{\text {th }}$ day) & & $292000(218000-380000)$ & & $212500(156500-380500)$ & 0.016 \\
\hline INR (discharge) & & $0.93(0.89-1)$ & & $1.09(0.94-1.34)$ & $<0.001$ \\
\hline D-dimer ( $5^{\text {th }}$ day) & & $720(440-1185)$ & & $1760(1110-3420)$ & $<0.001$ \\
\hline Ferritin ( $5^{\text {th }}$ day) & & $346.2(198-657)$ & & $692.2(347.4-1333.4)$ & 0.001 \\
\hline Ferritin (discharge) & & $386.95(203.5-756.1)$ & & 735.6 (439.6-1317) & $<0.001$ \\
\hline \multicolumn{6}{|c|}{$\begin{array}{l}\text { IQR: Interquartile range, BT: Body temperature, C: Celsius, } \mathrm{SO}_{2} \text { : Oxygen saturation (admission), WBC: White blood cell, ALT: Alanine aminotrans } \\
\text { ferase, AST: Aspartate aminotransferase, Na: Sodium, Ca: Calcium, CRP: C-reactive protein, INR: International normalized ratio. }\end{array}$} \\
\hline
\end{tabular}

therapy at admission. However, mortality rate was found significantly higher in patients requiring oxygen by reservoir masks or high-flow nasal oxygen (HFNO) at admission or during follow-up. Twentythree of the patients were transferred to the intensive care unit (Table 4).
In the multiple regression analysis performed for 30 day mortality variable, age, presence of heart failure, admission oxygen saturation, body temperature greater than 38.2, and ferritin level were determined as independent predictors. The odds ratios for 30-day mortality were 1.057 for each 1-year increase in age, 

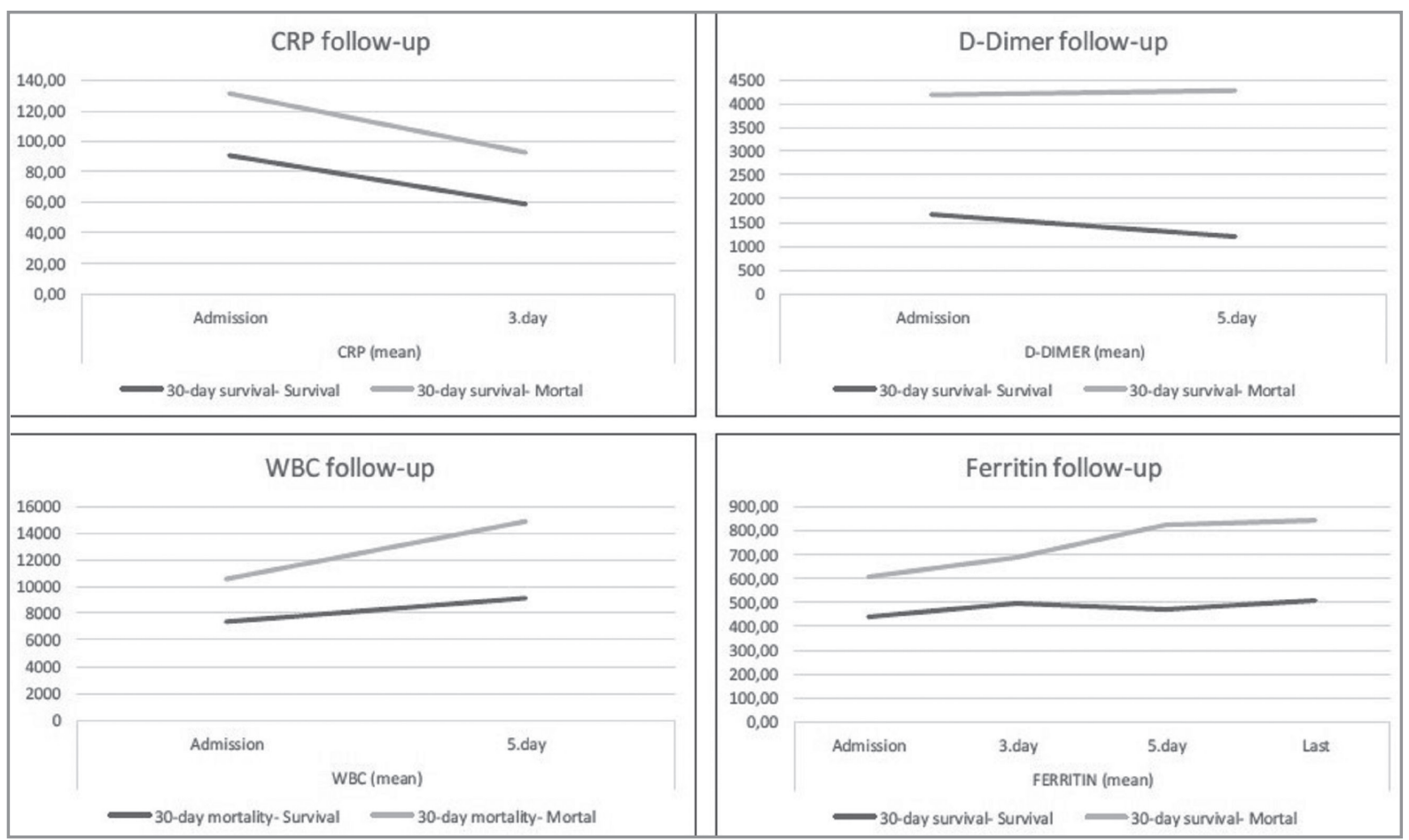

Figure 1. Biomarker levels in follow-up.

7.117 for the presence of congestive heart failure, 0.002 for each one-unit increase in admission oxygen saturation, 0.027 for body temperature above 38.2 degrees Celsius, and 1.0013 for each one unit increase in ferritin level [Equation: logit $(p)=1.623+$ $(0.055 \times$ age $)+(1.963 \times \mathrm{CHF})+\left(-0.079 \times \mathrm{SO}_{2}\right)+$ $(1.593 \times$ high BT $)+(0.001 \times$ ferritin $)]$ (Table 5$)$.

\section{DISCUSSION}

In this retrospective clinical study, the clinical features of COVID-19 patients were thoroughly reviewed to predict prognosis and mortality. Mean ages of the patients in the mortality group were older $(71.2 \mathrm{y})$, which is in line with the results of a prospective study demonstrating that being over the age of 65 is a risk factor for mortality (5). Similarly, in a study conducted on 3841 patients, mean ages in the survival and mortality groups have been reported as 54.7 and 73.4, respectively [(Odds Ratio $(\mathrm{OR}): 1.07)]$, and the ratio for male to female has been found as $3 / 2 r$ in the mortality group (1). Along these lines, in a study conducted as a single-center study in January 2020 in China, the very first study in which the mortality rates were investigated by sex, mortality rates were reported as $12.8 \%$ in male and $7.3 \%$ in female patients (6). In comparison, 30 day mortality rates were a bit higher in this study, $9.09 \%(n=12)$ in female and $17.5 \%(n=40)$ in male.

There was no statistically significant difference between the survival and mortality groups in terms of $\mathrm{BMI}$, but the minimum BMI levels were $>24$ in both groups. So, the fact that no significant difference was found between the groups in terms of BMI may be attributed to the fact that the groups were homogeneous and almost all of the patients were overweight or obese.

When the relationship between admission symptoms and mortality was examined, a relationship between headache, increased sputum, fatigue, shortness of breath and increased mortality was found in the literature. In contrast, no relationship was found between symptoms other than dyspnea and mortality or disease severity in this study (5). In a comprehensive study involving 1157 patients, mortality rates have been found significantly higher in advanced age and male patients, furthermore, the rate of referral to intensive care units has been detected higher in young patients of non-white ethnicity. Additionally, comorbidities such as DM, HT and chronic lung disease have been demonstrated to be significantly associated with mortality and the need for intensive 
Table 3. Univariate analysis in groups according to 30-day survival-imaging

\begin{tabular}{|c|c|c|c|}
\hline \multirow{3}{*}{ Variables } & \multicolumn{3}{|c|}{ 30-day survival } \\
\hline & Survival & Mortal & \multirow[b]{2}{*}{$\mathbf{p}$} \\
\hline & n $(\%)$ & n $(\%)$ & \\
\hline \multicolumn{4}{|l|}{ PA-CXR sign* } \\
\hline None & $35(97.2)$ & $1(2.8)$ & \multirow{3}{*}{0.109} \\
\hline Unilateral & $93(83.8)$ & $18(16.2)$ & \\
\hline Bilateral & $180(84.5)$ & $33(15.5)$ & \\
\hline CT-number of lobes- Median (IQR) ${ }^{\ddagger}$ & $4(2-5)$ & $5(3-5)$ & 0.072 \\
\hline \multicolumn{4}{|l|}{ CT (performed?) } \\
\hline Yes & $248(86.1)$ & $39(13.9)$ & \multirow[t]{2}{*}{0.360} \\
\hline No & $60(83.3)$ & $13(16.7)$ & \\
\hline \multicolumn{4}{|l|}{$\mathrm{CT} \operatorname{sign}^{\dagger}$} \\
\hline None & $7(100.0)$ & $0(0.0)$ & \multirow{3}{*}{0.405} \\
\hline Unilateral & $24(80.0)$ & $6(20.0)$ & \\
\hline Bilateral & $217(86.8)$ & $33(13.2)$ & \\
\hline \multicolumn{4}{|l|}{ CT- lobes ${ }^{\dagger}$} \\
\hline None & $7(100.0)$ & $0(0.0)$ & \multirow{4}{*}{0.225} \\
\hline Upper lobes & $14(100.0)$ & $0(0.0)$ & \\
\hline Bases & $93(88.6)$ & $12(11.4)$ & \\
\hline All lobes & $134(83.2)$ & 27 (16.8) & \\
\hline \multicolumn{4}{|l|}{ CT involvement ${ }^{\dagger}$} \\
\hline None & $7(100.0)$ & $0(0.0)$ & \multirow{4}{*}{0.029} \\
\hline Central & $8(100.0)$ & $0(0.0)$ & \\
\hline Peripheral & $150(90.4)$ & $16(9.6)$ & \\
\hline Diffuse & $83(78.3)$ & $23(21.7)$ & \\
\hline \multicolumn{4}{|l|}{ CT involvement* } \\
\hline Localized & $165(91.2)$ & $16(8.8)$ & \multirow{2}{*}{0.002} \\
\hline Diffuse & $83(78.3)$ & $23(21.7)$ & \\
\hline
\end{tabular}

care (7). Also, mortality rates have been found higher in patients with cardiovascular or cerebrovascular comorbidities (5). A meta-analysis has demonstrated hypertension, chronic lung diseases, cardiovascular disease and DM were high risk factors for mortality due to COVID-19 (8). In distinctive from, mortality rates were detected notably higher only in patients with heart failure and COPD in this study, which may be explained by the extent of the impairment in the immune status of the patients with different comorbidities compared to their healthy peers $(9,10)$. Intercalarily, the impairment in immunity may be the reason for the severe course of COVID-19 in patients with comorbidities. However, COVID-19 is a new disease and the immune response to this disease is not clearly understood. Various comorbidities report- ed as associated with COVID-19-induced mortality in several studies make it even more difficult to predict the prognosis of the disease.

In many studies in the literature, different results have been obtained in terms of blood cell counts associated with immune response. In a meta-analysis, high leukocyte and neutrophil counts and low lymphocyte counts have been found to be associated with COVID-19 severity (8). Risk scoring consisting of 12 parameters reported in another meta-analysis includes: over 40 years age, male sex, non-white race, $<93 \% \mathrm{SO}_{2}$, radiological severity score $>3$, neutrophil count $>8.0 \times 10^{9} / \mathrm{L}, \mathrm{CRP}>40 \mathrm{mg} / \mathrm{L}$, Albumin $<34 \mathrm{~g} / \mathrm{L}$, creatinine $>100 \mu \mathrm{mol} / \mathrm{L}, \mathrm{DM}, \mathrm{HT}$ and chronic lung disease (7). In our study, lymphocyte count was found to be statistically lower in the mortal group 
Uzel Şener M, Yıldız M, Kavurgacı S, Öztürk Ergür F, Şener A, Öztürk A.

Table 4. Univariate analysis in groups according to 30-day survival treatment and prognosis

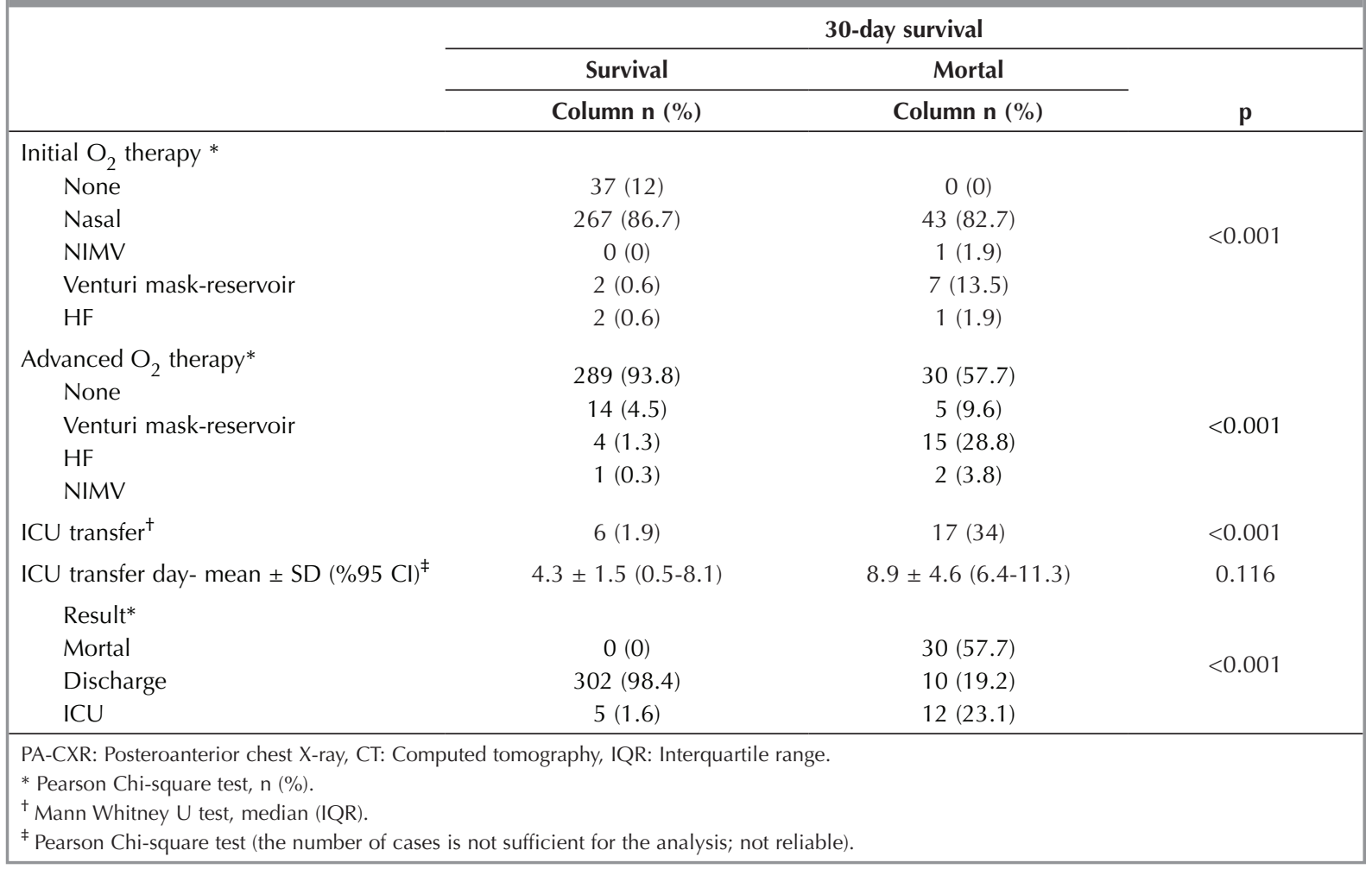

Table 5. Multiple logistic regression analysis for 30-day mortality

\begin{tabular}{|c|c|c|c|}
\hline Variables & $\mathbf{B}^{* *}$ & Sig. & Odds ratio* $(95 \% \mathrm{CI})$ \\
\hline \multicolumn{4}{|l|}{ Step 1a } \\
\hline Age & 0.055 & 0.015 & $1.057(1.011-1.105)$ \\
\hline $\operatorname{Sex}(1)$ & -0.173 & 0.756 & $0.841(0.283-2.501)$ \\
\hline Shortness of breath (1) & 0.298 & 0.614 & $1.347(0.422-4.296)$ \\
\hline COPD (1) & 0.325 & 0.608 & $1.384(0.400-4.787)$ \\
\hline $\mathrm{CHF}(1)$ & 1.963 & 0.011 & $7.117(1.579-32.087)$ \\
\hline $\mathrm{SO}_{2}$ (admission) & -0.079 & 0.002 & $0.924(0.878-0.973)$ \\
\hline $\mathrm{BT}(1)$ & 1.593 & 0.027 & $4.920(1.196-20.241)$ \\
\hline Lymphocyte & 0.000031 & 0.631 & $1.000(1.000-1.000)$ \\
\hline CRP & 0.001 & 0.811 & $1.001(0.994-1.007)$ \\
\hline D-dimer & -0.000085 & 0.256 & $1.000(1.000-1.000)$ \\
\hline Ferritin & 0.001 & 0.026 & $1.0013(1.000-1.002)$ \\
\hline Troponin & 0.008 & 0.107 & $1.008(0.998-1.018)$ \\
\hline CT-diffuse (1) & 0.763 & 0.144 & $2.146(0.771-5.968)$ \\
\hline Constant & 1.623 & 0.552 & 5.069 \\
\hline \multicolumn{4}{|c|}{$\begin{array}{l}\mathrm{Cl} \text { : Confidence interval, COPD: Chronic obstructive pulmonary disease, } \mathrm{CHF} \text { : Congestive heart failure, } \mathrm{SO}_{2} \text { : Oxygen saturation, CRP: C-reactiv } \\
\text { protein, } \mathrm{CT} \text { : Computed tomography, } \mathrm{BT} \text { : Body temperature (if }>38.2 \text { degrees Celsius). } \\
* * \text { Equation: logit }(\mathrm{p})=1.623+(0.055 \times \text { age })+(1.963 \times \mathrm{CHF})+\left(-0.079 \times \mathrm{SO}_{2}\right) \\
+(1.593 \times \text { high } \mathrm{BT})+(0.001 \times \text { ferritin })\end{array}$} \\
\hline
\end{tabular}


$\left(<750 \times 10^{9} / \mathrm{L}\right)$. Lymphopenia and neutrophilia were found to be associated with mortality.

In our study, increased CRP and creatinine were found to be associated with high mortality rate. Strong correlation between CRP increase and acute lung injury in COVID-19 cases has been previously shown in a study (11). In another analysis, it has been shown that CRP was higher in the group with high severity (12). In addition, increased CRP has been associated with heart damage, ARDS development, and death in COVID-19 patients (13).

Excessive immune response resulting in cytokine storm plays an important role in disease severity. High levels of cytokine release may occur with overactivation of leukocytes (14). In addition, this may cause neutrophil infiltration in pulmonary capillaries, organ damage and ARDS (15). Lymphocytes play an important role against bacterial, viral, fungal and parasitic infections and their blood levels increase; however, the immunological response that develops against COVID-19 is not clearly understood (16). On the other hand, according to a study conducted in Wuhan, myocardial damage has been detected in 82 of 416 patients (19.7\%), and significantly high leukocyte count and low lymphocyte count have been found in these patients $(p<0.001)(17)$.

Massive inflammatory response that develops against SARS-CoV-2 also affects the endothelial cells and, consequently, an increase in coagulation, disseminated intravascular coagulation and fibrin breakdown occurs (18). High fibrin and D-dimer levels may explain venous thromboembolism in severe COVID-19 patients $(19,20)$. Moreover, one study has found that pulmonary embolism and deep vein thrombosis were also detected in patients with severe COVID-19, which indicates that D-dimer could play an important role in predicting the severity of COVID-19 patients (8). In comparison, in this study, mean D-dimer levels in the survival and mortal groups were determined as 755 and 1440, respectively, supporting the findings in the literature.

Hyperferritinemia, which occurs as a result of excessive inflammation due to infection, is associated with the need for intensive care and high mortality and guides treatment changes to control inflammation in high-risk patients $(21,22)$. High ferritin was found to be associated with high mortality rate in our study. $\mathrm{Wu}$ et al. have found that high ferritin levels were associated with the development of ARDS but not associated with mortality (23). Cecconi et al. have emphasized that high ferritin levels can be used in the early period to identify patients in need of intensive care or with high mortality risk (24). In a large meta-analysis $(n=10614)$, ferritin was found to be elevated in patients with at least one comorbid disease, associated with severe liver damage, and predictive of the need for intensive care unit and mechanical ventilation (25).

In a study conducted with COVID-19 patients, troponin has been found to be high and increased gradually in the mortal group, and its levels were found to be stable in the surviving group (26). Therefore, monitoring of troponin levels in hospitalized patients may be necessary for early detection of cardiac damage. Malignant arrhythmias such as unstable ventricular tachycardia or ventricular fibrillation were found to be higher in patients with high troponin levels $(p<$ 0.001) (27). Similarly, in our study, mortality was found higher in patients with high levels of troponin at admission.

In COVID-19 cases, chest X-ray can be seen superior to other imaging methods because it is a common, easily accessible and easy-to-use tool. Diffuse infiltration in chest X-ray is considered as a predictor for intensive care and mortality (7). Already, the American College of Radiology, the Society of Thoracic Radiology and $\mathrm{WHO}$ do not recommend Thoracic CT scan for screening and diagnostic purposes $(28,29)$. However, in some local approaches, it is still recommended to perform CT scans to determine severity (30). We think that follow-up with chest X-ray is more appropriate due to the need to minimize movement in hypoxic patients and high admission burden. In our study, no significant difference was found in the mortality rate between patients with unilateral and bilateral involvement in chest X-ray (Table 3). Initial chest $\mathrm{X}$-ray findings may be misleading in determining prognosis. During the expected cytokine storm period, findings may increase, or new findings may develop on chest X-ray. Chest X-ray at admission is not predictive for prognosis, therefore we think that bedside chest X-ray performed during follow-up is necessary.

In this study, in-hospital mortality was found as $11.7 \%$, whereas 30 -day mortality was found as $14.4 \%$. In the multiple regression analysis in terms of 30-day mortality rate, age, presence of heart failure, admission $\mathrm{SO}_{2}$, body temperature greater than 38.2, 
and ferritin level were determined as independent predictors. As expected, mortality rate was found to be higher in patients who needed supplemental oxygen treatment at the beginning and who required high flow oxygen therapy during the follow-up depending on the $\mathrm{SO}_{2}$ level.

\section{CONCLUSION}

In summary, the clinical findings of the patients at admission are more important than laboratory parameters in predicting disease prognosis. However, we can say that laboratory parameters provide more reliable information than radiological examinations. The relationship between clinical markers and prognosis is very important in terms of accurately directing the healthcare services during the COVID-19 pandemic and revealing the importance of fast and efficient sharing of the clinical data.

Ethical Committee Approval: The study was obtained from University of Health Sciences, Ataturk Chest Diseases and Chest Surgery Training and Research Hospital Medical Specialty Education Board (Decision no: 696, Date: 08.10.2020)

\section{CONFLICT of INTEREST}

The authors of this meta-analysis declare that they have no conflict of interest.

\section{AUTHORSHIP CONTRIBUTIONS}

\section{Concept/Design: MUŞ, AÖ, MY}

Analysis/Interpretation: MUŞ, AÖ, SK, AŞ

Data Acqusition: MUŞ, MY, SK, FÖE

Writing: MUŞ, AŞ, AÖ

Clinical Revision: All of authors

Final Approval: All of authors

\section{REFERENCES}

1. Yadaw $A S, L i$ YC, Bose $S$, lyengar $R$, Bunyavanich $S$, Pandey G. Clinical features of COVID-19 mortality: development and validation of a clinical prediction model. Lancet Digit Health 2020;2(10):e516-e525.

2. Guan WJ, Ni ZY, Hu Y, Liang WH, Ou CQ, He JX, et al. Clinical characteristics of coronavirus disease 2019 in China. N Engl J Med 2020; 382: 1708-20.

3. Siordia JA. Epidemiology and clinical features of COVID19: a review of current literature. I Clin Virol 2020; 127: 10435.
4. Kinross P, Suetens C, Gomes Dias J, Alexakis L, Wijermans $A$, Colzani $E$, et al. Rapidly increasing cumulative incidence of coronavirus disease (COVID-19) in the European Union/European Economic Area and the United Kingdom, 1 January to 15 March 2020. Euro Surveill Mar 2020; 25(11): 2000285.

5. Du RH, Liang $L R$, Yang $C Q$, Wang $W$, Cao $T Z, L i M$, et al. Predictors of mortality for patients with COVID-19 pneumonia caused by SARS-CoV-2: a prospective cohort study. Eur Respir J 2020; 55(5): 2000524.

6. Meng Y, Wu P, Lu W, Liu K, Ma K, Huang L, et al. (2020) Sex-specific clinical characteristics and prognosis of coronavirus disease-19 infection in Wuhan, China: a retrospective study of 168 severe patients. PLoS Pathog 16(4): e1008520.

7. Galloway JB, Norton S, Barker RD, Brookes A, Carey I, Clarke $B D$, et al. A clinical risk score to identify patients with COVID-19 at high risk of critical care admission or death: an observational cohort study. J Infect 2020; 81(2): 282-8.

8. Mudatsir M, Fajar JK, Wulandari L, Soegiarto G, Ilmawan $M$, Purnamasari Y, et al. Predictors of COVID-19 severity: a systematic review and meta-analysis. F1000Res 2020; 9: 1107.

9. Ferlita S, Yegiazaryan A, Noori N, Lal G, Nguyen T, To K, et al. Type 2 Diabetes Mellitus and altered immune system leading to susceptibility to pathogens, especially Mycobacterium tuberculosis. J Clin Med 2019; 8(12): 2219.

10. Lazzerini PE, Hamilton RM, Boutjdir M. Editorial: cardioimmunology: inflammation and immunity in cardiovascular disease. Front Cardiovasc Med 2019; 6: 181.

11. Liu $Y$, Yang $Y$, Zhang $C$, Huang $F$, Wang $F$, Yuan J, et al. Clinical and biochemical indexes from 2019-nCoV infected patients linked to viral loads and lung injury. Science China Life Sci 2020; 63(3): 364-74.

12. Shang W, Dong J, Ren Y, Tian M, Li W, Hu J et al. The value of clinical parameters in predicting the severity of COVID-19. J Med Virol 2020; 92(10): 2188-92.

13. Terpos E, Ntanasis-Stathopoulos I, Elalamy I, Kastritis E, Sergentanis $T N$, Politou $M$, et al. Hematological findings and complications of COVID-19. Am J Hematol 2020; 95(7): 834-47.

14. Coperchini F, Chiovato L, Croce L, Magri F, Rotondi M. The cytokine storm in COVID-19: an overview of the involvement of the chemokine/chemokine-receptor system. Cytokine Growth Factor Rev 2020; 53: 25-32.

15. Mikacenic C, Moore R, Dmyterko V, West TE, Altemeier WA, Liles WC, et al. Neutrophil extracellular traps (NETS) are increased in the alveolar spaces of patients with ventilator associated pneumonia. Crit Care 2018; 22(1): 358.

16. Koyasu S, Moro K. Role of innate lymphocytes in infection and inflammation. Front Immunol 2012; 3: 101. 
17. Shi S, Qin M, Shen B, Cai Y, Liu T, Yang F, et al. Association of cardiac injury with mortality in hospitalized patients with COVID-19 in Wuhan, China. JAMA Cardiol 2020; e200950.

18. Varga Z, Flammer AJ, Steiger $P$, Haberecker $M$, Andermatt $R$, Zinkernagel $A S$, et al. Endothelial cell infection and endotheliitis in COVID-19. Lancet 2020; 395(10234): 1417-18.

19. Marietta M, Ageno W, Artoni A, De Candia E, Gresele P, Marchetti M, et al. COVID-19 and haemostasis: a position paper from Italian Society on Thrombosis and Haemostasis (SISET). Blood Transfus 2020; 18(3): 167-9.

20. Becker RC. COVID-19 update: Covid-19-associated coagulopathy. J Thromb Thrombolysis 2020; 50(1): 54-67.

21. Kernan KF, Carcillo JA. Hyperferritinemia and inflammation. Int Immunol 2017; 29(9): 401-9.

22. Carcillo JA, Sward K, Halstead ES, Telford R, JimenezBacardi A, Shakoory B, et al. A systemic inflammation mortality risk assessment contingency table for severe sepsis. Pediatr Crit Care Med 2017; 18(2): 143-50.

23. Wu C, Chen X, Cai Y, Xia J, Zhou X, Xu S, et al. Risk factors associated with acute respiratory distress syndrome and death in patients with coronavirus disease 2019 pneumonia in Wuhan, China. JAMA Intern Med 2020; 180(7): 934-43.

24. Cecconi $M$, Piovani D, Brunetta E, Aghemo A, Greco M, Ciccarelli $M$, et al. Early predictors of clinical deterioration in a cohort of 239 patients hospitalized for Covid-19 infection in Lombardy, Italy. I Clin Med 2020; 9(8): 2429.
25. Cheng L, Li H, Li L, Liu C, Yan S, Chen H, et al. Ferritin in the coronavirus disease 2019 (COVID-19): a systematic review and meta-analysis. I Clin Lab Anal 2020; 34(10): e23618.

26. Zhou F, Yu T, Du R, Fan G, Liu Y, Liu Z, et al. Clinical course and risk factors for mortality of adult inpatients with COVID-19 in Wuhan, China: a retrospective cohort study. Lancet 2020; 395(10229): 1054-62.

27. Guo $T$, Fan $Y$, Chen $M, W u X$, Zhang $L, H e ~ T$, et al. Cardiovascular implications of fatal outcomes of patients with coronavirus disease 2019 (COVID-19). JAMA Cardiol 2020; 5(7): 811-8.

28. Simpson S, Kay FU, Abbara S, Bhalla S, Chung JH, Chung $M$, et al. Radiological Society of North America Expert Consensus Statement on reporting Chest CT findings related to COVID-19. Endorsed by the Society of Thoracic Radiology, the American College of Radiology, and RSNAsecondary publication. I Thorac Imaging 2020; 35(4): 219-27.

29. AkI EA, Blazic I, Yaacoub S, Frija G, Chou R, Appiah JA, et al. Use of Chest imaging in the diagnosis and management of COVID-19: a WHO rapid advice guide. Radiology 2020; 298(2): E63-E69.

30. Mahdavi A, Haseli S, Mahdavi A, Bakhshayeshkaram M, Foroumandi $M$, Nekooghadam $S M$, et al. The role of repeat Chest CT Scan in the COVID-19 Pandemic. Acad Radiol 2020; 27(7): 1049-50. 